УДК 631.53.01:633.15:631.811.98:631.67(477.7)

DOI https://doi.org/10.32848/agrar.innov.2021.5.22

\title{
ЕФЕКТИВНІСТЬ ЗАСТОСУВАННЯ БІОПРЕПАРАТІВ ПІД ЧАС ВИРОЩУВАННЯ ЛІНІЙ-БАТЬКІВСЬКИХ КОМПОНЕНТІВ ГІБРИДІВ КУКУРУДЗИ ЗА РІЗНОЇ ГУСТОТИ РОСЛИН В УМОВАХ КРАПЛИННОГО ЗРОШЕННЯ
}

\author{
МАРЧЕНКО Т.Ю. - доктор сільськогосподарських наук, старший науковий співробітник \\ http://orcid.org/0000-0001-6994-3443 \\ Інститут зрошуваного землеробства Національної академії аграрних наук України \\ ЛАВРИНЕНКО Ю.О. - доктор сільськогосподарських наук, професор, академік \\ Національної академії аграрних наук України \\ https://orcid.org/0000-0001-9442-8793 \\ Інститут зрошуваного землеробства Національної академії аграрних наук України \\ КИРПА М.Я. - доктор сільськогосподарських наук, професор \\ https://orcid.org/0000-0002-6893-8180 \\ Інститут зернових культур Національної академії аграрних наук України \\ СТАСІB О.Ф. - кандидат економічних наук, доцент \\ https://orcid.org/0000-0003-3737-739X \\ Інститут сільського господарства Карпатського регіону \\ Національної академії аграрних наук України
}

Постановка проблеми. Удосконалення сортових технологій і добір гібридів кукурудзи з певним рівнем адаптивності до агроекологічних зон та технологій $€$ підґрунтям стабільності тренду зростання виробництва зерна в Україні [1-3]. Проте використання сучасних інноваційних адаптивних гібридів вимагає розроблення сортових технологій прискореного розмноження ліній-батьківських компонентів для забезпечення необхідної кількості насіння для ділянок гібридизації $[4 ; 5]$.

Аналіз останніх досліджень і публікацій. В останні роки широкої популяризації та поширення в аграрному виробництві набуває напрям, спрямований на екологічність землеробства, що передбачає застосування екологічно безпечних засобів захисту рослин від шкідливих організмів та стимулювання росту і розвитку рослин біологічними препаратами [6; 7]. Біологічний метод захисту рослин (biolo-gical control or biocontrol) у його вузькому класичному розумінні $є$ методом боротьби зі шкідниками, бур'янами і хворобами рослин із використанням природних ворогів. Він ґрунтується на природних механізмах («хижак - жертва», «паразит - господар») й активному втручанні людини в процес регуляції та пригнічення шкідників і патогенних організмів [8; 9].

Вивчення впливу біопрепаратів із рістрегулюючими властивостями $€$ перспективним та актуальним, особливо в умовах змін клімату. Аналіз літературних даних указує на те, що застосування біопрепаратів із захисними та рістстимулюючими функціями сприяє реалізації закладених в організмі потенційних можливостей, у тому числі певних імунних реакцій, підвищує продуктивність рослин та сприяє реалізації генотипових задатків сортів та гібридів. Питанню широкого використання біопрепаратів у землеробстві приділяють значну увагу в більшості економічно розвинених країн: Франції, Великій Британії, Німеччині, Швейцарії, США [10].

Поруч із біологічними методами захисту рослин великого значення набувають й агротехнічні засоби впливу на продуктивність гібридів та ліній-батьківських компонентів, тому першочерговим завданням адап- тивної технології вирощування кукурудзи є поєднання селекційних розробок, заходів захисту рослин та агротехнічних прийомів [11].

Важливим елементом технології вирощування ліній та гібридів кукурудзи в умовах Південного Степу $є$ густота стояння рослин. Фактор «густота ценозу» особливо важливий в умовах природного зволоження, за різних режимів зрошення та способів поливу і має специфічний вплив на генотипові особливості гібриду кукурудзи (батьківської лінії) та групу ФАО [12].

Густота рослин кукурудзи в посіві має суттєвий вплив на фотосинтетичні та біометричні показники, що опосередковано впливають на врожайність зерна та насіння гібридів і ліній кукурудзи [13-15].

Мета статті. Удосконалення існуючої технології вирощування ліній-батьківських компонентів інноваційних гібридів кукурудзи на зрошуваних землях шляхом визначення впливу нових біопрепаратів за різної густоти рослин на врожайність насіння та економічну ефективність за умов зрошення в Південному Степу. Мета досягається за рахунок підбору та науково обґрунтування найбільш ефективних препаратів для відповідних груп стиглості батьківських компонентів за краплинного зрошення, що дасть змогу підвищити рівень урожайності батьківських компонентів кукурудзи за рахунок використання екологічно безпечних біопрепаратів та визначення оптимальної щільності ценозу.

Матеріали та методика досліджень. Дослідження проводилися у 2019-2020 рр. на дослідному полі Інституту зрошуваного землеробства НААН згідно з ПНД 10 НААН за завданням 10.00.04.09.П «Визначити вплив біопрепаратів на продуктивність інноваційних гібридів кукурудзи інтенсивного типу та їхніх батьківських форм в умовах краплинного зрошення».

Фактор А - різні за групами стиглості батьківські лінії ДК445, ДК411, ДК281, ДК247, що входять до родоводу гібридів Степовий, Скадовський, Азов, Арабат, Чонгар, Віра, Олешківський, Гілея та інших гібридів селекції Інституту зрошуваного землероб- 
ства НААН та ДУ «Інститут зернових культур НААН». Фактор В - густота рослин батьківських фрорм - 70, 80, 90 тис рослин/га. Фактор С - обробка батьківських компонентів кукурудзи інноваційними вітчизняними біопрепаратами Флуоресцин БТ, Трихопсин БТ, Біоспектр БТ. Біопрепаратами обробляли насіння перед сівбою та рослини в процесі вегетації згідно з рекомендаціями Інженерно-технологічного інституту «Біотехніка» НААН (м. Одеса) [16].

Характеристика біопрепаратів: Трихопсин БТ. Мікробіологічний препарат інсекто-фунгіцидної та рістстимулювальної дії. Діючою основою препарату є міцелій, спори гриба з роду Trichoderma та ризосферні бактерії роду Pseudomonas з титром не нижче 2,0·1010 КУО/ $\mathrm{CM}^{3}$, а також біологічно активні речовини, що продукують штами-продуценти.

Флуорисцин БТ. Мікробіологічний препарат фрунгіцидної та рістстимулювальної дії. Містить ризосфрерні бактеpiї роду Pseudomonas з титром не нижче 5,0·109 КУО/ $\mathrm{cm}^{3}$, а також біологічно активні речовини (БАР): френазин-карбонові кислоти, сидерофори, цитокініни.

Біоспектр БТ. Мікробіологічний препарат інсекто-фрунгіцидної дії. Містить ризоссрерні бактерії роду Pseudomonas 3 титром не нижче $5,0 \cdot 10^{9} \mathrm{KУO} / \mathrm{cm}^{3}$, біологічно активні речовини (БАР): кислоти з роду фена- зин-карбонових, комплекс активних пігментів, які є діючими фракторами в препараті.

Агротехніка вирощування загальноприйнята для умов зрошення і відповідала вимогам технологій виробництва кукурудзи для агроекологічних умов степової зони України. У період вегетації проводилися фенологічні спостереження та біометричні обліки згідно з відповідними методиками.

Досліди проводили в умовах зрошення. Основним критерієм планування режиму зрошення був рівень передполивної вологості ґрунту (РПВГ). Біологічно оптимальним режимом зрошення кукурудзи вважається такий режим, за якого на всіх етапах органогенезу РПВГ підтримується на рівні $80 \%$ НВ, котрий і було застосовано в досліді. Методика досліджень загальноприйнята для умов зрошення та селекційних досліджень з кукурудзою [17].

Результати досліджень. Досліджувані біопрепарати проявили позитивний вплив на підвищення стійкості ліній-батьківських компонентів до грибних хвороб та шкідників, про що було повідомлено в попередніх публікаціях [18].

Окрім фунгіцидної та інсектицидної дії, ці препарати показали й рістстимулюючу ефективність. Стимуляція ростових процесів проявилася передусім на фотосинтетичних показниках (табл. 1).

Таблиця 1 - Динаміка наростання площі асиміляційної поверхні однієї рослини батьківських форм кукурудзи ФАО 190-290

\begin{tabular}{|c|c|c|c|c|c|}
\hline \multirow{2}{*}{$\begin{array}{c}\text { Лінія } \\
\text { (фактор A) }\end{array}$} & \multirow{2}{*}{$\begin{array}{c}\text { Густота } \\
\text { тис шт./га } \\
\text { (фактор В) }\end{array}$} & \multirow{2}{*}{$\begin{array}{c}\text { Обробіток біопрепаратами } \\
\text { (фактор С) }\end{array}$} & \multicolumn{3}{|c|}{$\begin{array}{c}\text { Площа асиміляційної поверхні } \\
\text { за фразами розвитку, м²/рослину }\end{array}$} \\
\hline & & & 12-13 листків & $\begin{array}{l}\text { цвітіння } \\
\text { качанів }\end{array}$ & $\begin{array}{c}\text { фрізіологічна } \\
\text { стиглість зерна }\end{array}$ \\
\hline \multirow{12}{*}{ ДК 281} & \multirow{4}{*}{70} & Без обробки & 0,203 & 0,289 & 0,265 \\
\hline & & Флуоресцин БТ & 0,207 & 0,322 & 0,281 \\
\hline & & Трихопсин БТ & 0,200 & 0,315 & 0,274 \\
\hline & & Біоспектр БТ & 0,200 & 0,313 & 0,271 \\
\hline & \multirow{4}{*}{80} & Без обробки & 0,205 & 0,239 & 0,228 \\
\hline & & Флуоресцин БТ & 0,239 & 0,271 & 0,233 \\
\hline & & Трихопсин БТ & 0,234 & 0,290 & 0,259 \\
\hline & & Біоспектр БТ & 0,232 & 0,259 & 0,257 \\
\hline & \multirow{4}{*}{90} & Без обробки & 0,202 & 0,264 & 0,230 \\
\hline & & Флуоресцин БТ & 0,207 & 0,289 & 0,265 \\
\hline & & Трихопсин БТ & 0,210 & 0,283 & 0,259 \\
\hline & & Біоспектр БТ & 0,212 & 0,281 & 0,257 \\
\hline \multirow{12}{*}{ ДК 247} & \multirow{4}{*}{70} & Без обробки & 0,244 & 0,378 & 0,358 \\
\hline & & Флуоресцин БТ & 0,256 & 0,406 & 0,371 \\
\hline & & Трихопсин БТ & 0,249 & 0,394 & 0,365 \\
\hline & & Біоспектр БТ & 0,246 & 0,392 & 0,361 \\
\hline & \multirow{4}{*}{80} & Без обробки & 0,245 & 0,352 & 0,339 \\
\hline & & Флуоресцин БТ & 0,263 & 0,388 & 0,381 \\
\hline & & Трихопсин БТ & 0,257 & 0,363 & 0,384 \\
\hline & & Біоспектр БТ & 0,251 & 0,365 & 0,372 \\
\hline & \multirow{4}{*}{90} & Без обробки & 0,250 & 0,265 & 0,349 \\
\hline & & Флуоресцин БТ & 0,268 & 0,283 & 0,362 \\
\hline & & Трихопсин БТ & 0,259 & 0,275 & 0,356 \\
\hline & & Біоспектр БТ & 0,257 & 0,280 & 0,361 \\
\hline \multirow{3}{*}{\multicolumn{2}{|c|}{$\mathrm{HIP}_{05}$, см для факторів: }} & A & 0,043 & 0,052 & 0,024 \\
\hline & & $\mathrm{B}$ & 0,081 & 0,21 & 0,029 \\
\hline & & $\mathrm{C}$ & 0,079 & 0,080 & 0,025 \\
\hline
\end{tabular}


Найбільш істотний вплив біопрепаратів на площу листкової поверхні у скоростиглих ліній спостерігався у фазу цвітіння качанів. Серед біопрепаратів найбільш ефрективним був Флуоресцин БТ. Площа листкової поверхні у лінії ДК281 збільшувалась на 4,0-11,4\%. Окрім впливу ростових регуляторів на площу листкової поверхні, спостерігався значний вплив також щільності ценозу та генотипових особливостей ліній. Генотипові особливостей ліній, перш за все, пов'язані з групою стиглості батьківських ліній. Площа листкової поверхні істотно збільшувалася зі зростанням групи ФАО. Так, у середньоранньої лінії ДК247 площа листкової поверхні у фазу цвітіння сягала 0,290-0,406 м² на рослину.

У середньопізньої лінії ДК411 та середньопізньої ДК445 також максимальні значення площі листкової поверхні рослини на всіх варіантах досліду спостерігали у фазу цвітіння качанів. Найбільшим цей показник був за густотою 70 тис шт./га у середньопізньої лінії ДК445 за використання препарату Флуоресцин БТ та становив 0,419 м²/рослину (табл. 2).

За обробітку препаратом Флуоресцин БТ усі лінії-батьківські компоненти гібридів кукурудзи мали найвищі показники площі листкової поверхні рослин. У наступні фрази розвитку рослин культури відбувалося незначне зменшення даного показника.
Дисперсійна обробка показників площі листкової поверхні у фазу цвітіння качанів дала змогу встановити частку впливу досліджуваних фракторів на формування асиміляційної листової поверхні (рис. 1).

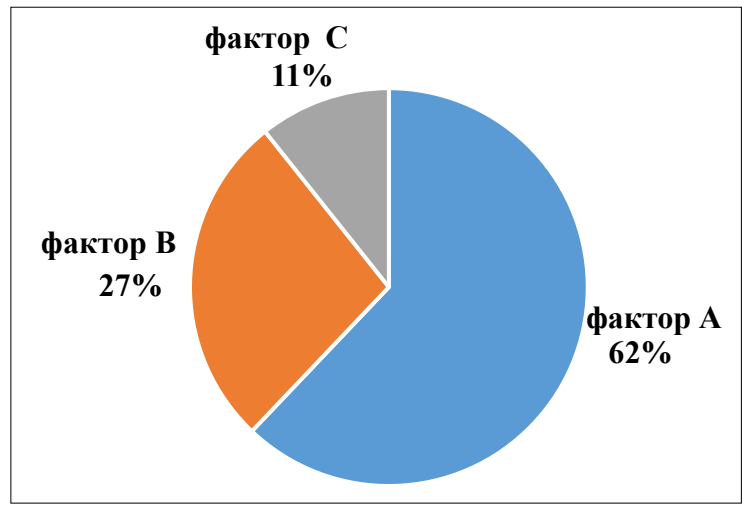

Puc. 1. Частка впливу факторів досліду на формування асиміляційної поверхні однієї рослини батьківських форм (ліній кукурудзи), \%

Установлено, що найбільший вплив площу листків рослин ліній кукурудзи мала батьківська форма, частка іiї впливу становила $62,1 \%$. Густота рослин та обробіток

Таблиця 2 - Динаміка наростання площі асиміляційної поверхні однієї рослини батьківських форм кукурудзи ФАО 390-430

\begin{tabular}{|c|c|c|c|c|c|}
\hline \multirow{2}{*}{$\begin{array}{c}\text { Лінія } \\
\text { (фактор A) }\end{array}$} & \multirow{2}{*}{$\begin{array}{c}\text { Густота тис шт/га } \\
\text { (фрактор В) }\end{array}$} & \multirow{2}{*}{$\begin{array}{c}\text { Обробіток біопрепаратами } \\
\text { (фактор С) }\end{array}$} & \multicolumn{3}{|c|}{$\begin{array}{c}\text { Площа асиміляційної поверхні за фазами } \\
\text { розвитку, м²/рослину }\end{array}$} \\
\hline & & & 12-13 листків & $\begin{array}{l}\text { цвітіння } \\
\text { качанів }\end{array}$ & $\begin{array}{c}\text { фізіологічна } \\
\text { стиглість } \\
\text { зерна } \\
\end{array}$ \\
\hline \multirow{12}{*}{ ДК 411} & \multirow{4}{*}{70} & Без обробки & 0,245 & 0,397 & 0,368 \\
\hline & & Флуоресцин БТ & 0,273 & 0,418 & 0,401 \\
\hline & & Трихопсин БТ & 0,263 & 0,413 & 0,394 \\
\hline & & Біоспектр БТ & 0,261 & 0,411 & 0,392 \\
\hline & \multirow{4}{*}{80} & Без обробки & 0,243 & 0,391 & 0,366 \\
\hline & & Флуоресцин БТ & 0,268 & 0,417 & 0,400 \\
\hline & & Трихопсин БТ & 0,262 & 0,411 & 0,391 \\
\hline & & Біоспектр БТ & 0,261 & 0,410 & 0,988 \\
\hline & \multirow{4}{*}{90} & Без обробки & 0,242 & 0,395 & 0,363 \\
\hline & & Флуоресцин БТ & 0,259 & 0,415 & 0,397 \\
\hline & & Трихопсин БТ & 0,256 & 0,410 & 0,389 \\
\hline & & Біоспектр БТ & 0,254 & 0,409 & 0,385 \\
\hline \multirow{12}{*}{ ДК 445} & \multirow{4}{*}{70} & Без обробки & 0,250 & 0,404 & 0,374 \\
\hline & & Флуоресцин БТ & 0,269 & 0,419 & 0,403 \\
\hline & & Трихопсин БТ & 0,268 & 0,417 & 0,401 \\
\hline & & Біоспектр БТ & 0,261 & 0,416 & 0,400 \\
\hline & \multirow{4}{*}{80} & Без обробки & 0,249 & 0,397 & 0,373 \\
\hline & & Флуоресцин БТ & 0,263 & 0,413 & 0,402 \\
\hline & & Трихопсин БТ & 0,262 & 0,411 & 0,399 \\
\hline & & Біоспектр БТ & 0,261 & 0,410 & 0,398 \\
\hline & \multirow{4}{*}{90} & Без обробки & 0,247 & 0,396 & 0,372 \\
\hline & & Флуоресцин БТ & 0,257 & 0,407 & 0,399 \\
\hline & & Трихопсин БТ & 0,256 & 0,404 & 0,396 \\
\hline & & Біоспектр БТ & 0,255 & 0,401 & 0,395 \\
\hline \multirow{3}{*}{\multicolumn{2}{|c|}{$\mathrm{HIP}_{05}$, см для факторів: }} & A & 0,084 & 0,074 & 0,028 \\
\hline & & $\mathrm{B}$ & 0,093 & 0,023 & 0,033 \\
\hline & & C & 0,082 & 0,086 & 0,021 \\
\hline
\end{tabular}




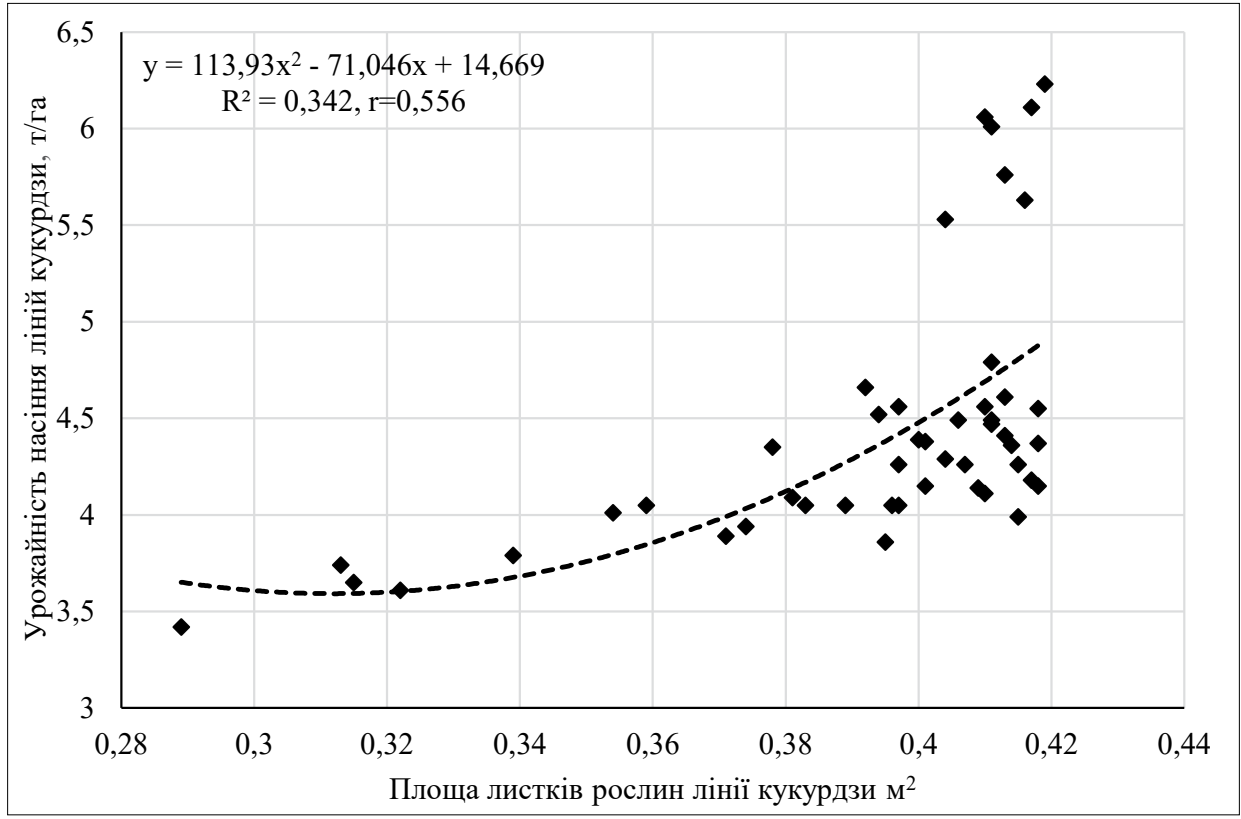

Рис. 2. Поліноміальна лінія тренду залежності площі листків рослин лінії кукурудзи та врожайності насіння

Таблиця 3 - Економічна ефективність вирощування батьківських форм гібридів кукурудзи ФАО 190-290 залежно від густоти та обробки препаратами (2019-2020рр.)

\begin{tabular}{|c|c|c|c|c|c|c|c|c|}
\hline 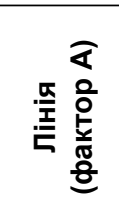 & 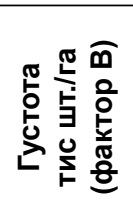 & 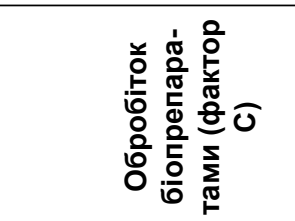 & 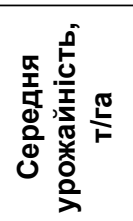 & 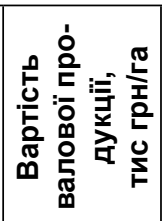 & 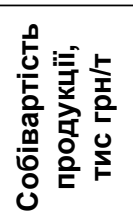 & 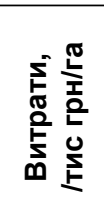 & 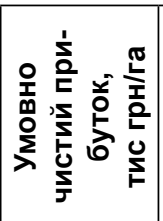 & 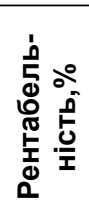 \\
\hline \multirow{12}{*}{ ДК 281} & \multirow{4}{*}{70} & Контроль (без обр.) & 3,42 & 99,2 & 31,67 & 40,22 & 59,0 & 147 \\
\hline & & Флуоресцин БТ & 3,61 & 104,7 & 30,07 & 40,50 & 64,2 & 158 \\
\hline & & Трихопсин БТ & 3,65 & 105,9 & 29,8 & 40,65 & 65,2 & 160 \\
\hline & & Біоспектр БТ & 3,74 & 108,5 & 29,05 & 40,71 & 67,8 & 166 \\
\hline & \multirow{4}{*}{80} & Контроль (без обр.) & 3,79 & 109,9 & 28,58 & 40,22 & 69,7 & 173 \\
\hline & & Флуоресцин БТ & 3,89 & 112,8 & 27,91 & 40,53 & 72,3 & 178 \\
\hline & & Трихопсин БТ & 4,01 & 116,3 & 27,13 & 40,55 & 75,7 & 187 \\
\hline & & Біоспектр БТ & 4,05 & 117,5 & 26,82 & 40,59 & 76,9 & 189 \\
\hline & \multirow{4}{*}{90} & Контроль (без обр.) & 3,94 & 114,3 & 27,49 & 40,22 & 74,0 & 184 \\
\hline & & Флуоресцин БТ & 4,05 & 117,5 & 26,81 & 40,51 & 76,9 & 190 \\
\hline & & Трихопсин БТ & 4,05 & 117,5 & 26,86 & 40,65 & 76,8 & 189 \\
\hline & & Біоспектр БТ & 4,09 & 118,6 & 26,56 & 40,72 & 77,9 & 191 \\
\hline \multirow{15}{*}{ ДК 247} & \multirow{4}{*}{70} & Контроль (без обр.) & 4,35 & 126,2 & 24,9 & 40,22 & 85,9 & 214 \\
\hline & & Флуоресцин БТ & 4,49 & 130,2 & 24,18 & 40,53 & 89,7 & 221 \\
\hline & & Трихопсин БТ & 4,52 & 131,1 & 24,07 & 40,55 & 90,5 & 223 \\
\hline & & Біоспектр БТ & 4,66 & 135,1 & 23,31 & 40,77 & 94,4 & 231 \\
\hline & \multirow{4}{*}{80} & Контроль (без обр.) & 4,39 & 127,3 & 24,67 & 40,22 & 87,1 & 217 \\
\hline & & Флуоресцин БТ & 4,55 & 132,0 & 23,86 & 40,53 & 91,4 & 226 \\
\hline & & Трихопсин БТ & 4,61 & 133,7 & 23,6 & 40,74 & 93,0 & 228 \\
\hline & & Біоспектр БТ & 4,79 & 138,9 & 22,68 & 40,77 & 98,1 & 241 \\
\hline & \multirow{4}{*}{90} & Контроль (без обр.) & 4,15 & 120,4 & 26,1 & 40,22 & 80,1 & 199 \\
\hline & & Флуоресцин БТ & 4,15 & 120,4 & 26,16 & 40,55 & 79,8 & 197 \\
\hline & & Трихопсин БТ & 4,26 & 123,5 & 25,54 & 40,74 & 82,8 & 203 \\
\hline & & Біоспектр БТ & 4,36 & 126,4 & 24,92 & 40,77 & 85,7 & 210 \\
\hline & & HIP 05 для фактора A & 0,19 & & & & & \\
\hline & & HIP 05 для фактора В & 0,15 & & & & & \\
\hline & & HIP $_{05}$ для фрактора C & 0,13 & & & & & \\
\hline
\end{tabular}


Таблиця 4 - Економічна ефективність вирощування батьківських форм гібридів кукурудзи ФАО 390-430 залежно від густоти та обробки препаратами (2019-2020 рр.)

\begin{tabular}{|c|c|c|c|c|c|c|c|c|}
\hline 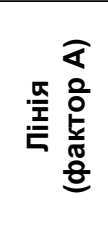 & 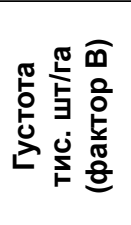 & $\begin{array}{c}\text { Обробіток біопрепаратами } \\
\text { (фрактор С) }\end{array}$ & 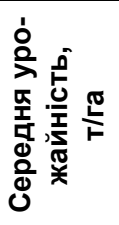 & 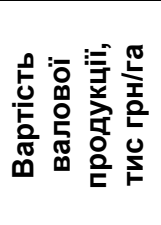 & 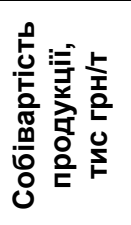 & 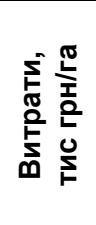 & 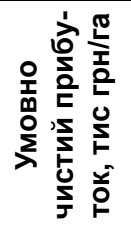 & 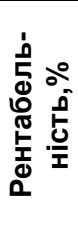 \\
\hline \multirow{12}{*}{ ДК 411} & \multirow{4}{*}{70} & Контроль (без обр.) & 4,26 & 123,5 & 25,42 & 40,22 & 83,3 & 207 \\
\hline & & Флуоресцин БТ & 4,37 & 126,7 & 24,84 & 40,55 & 86,2 & 213 \\
\hline & & Трихопсин БТ & 4,41 & 127,9 & 24,67 & 40,74 & 87,2 & 214 \\
\hline & & Біоспектр БТ & 4,47 & 129,6 & 24,3 & 40,77 & 88,9 & 218 \\
\hline & \multirow{4}{*}{80} & Контроль (без обр.) & 4,05 & 117,5 & 26,74 & 40,22 & 77,2 & 192 \\
\hline & & Флуоресцин БТ & 4,18 & 121,2 & 25,97 & 40,55 & 80,7 & 199 \\
\hline & & Трихопсин БТ & 4,49 & 130,2 & 24,23 & 40,74 & 89,5 & 220 \\
\hline & & Біоспектр БТ & 4,56 & 132,2 & 23,82 & 40,77 & 91,5 & 224 \\
\hline & \multirow{4}{*}{90} & Контроль (без обр.) & 3,86 & 111,9 & 28,06 & 40,22 & 71,7 & 178 \\
\hline & & Флуоресцин БТ & 3,99 & 115,7 & 27,21 & 40,55 & 75,2 & 185 \\
\hline & & Трихопсин БТ & 4,11 & 119,2 & 26,47 & 40,74 & 78,5 & 193 \\
\hline & & Біоспектр БТ & 4,14 & 120,1 & 26,24 & 40,77 & 79,3 & 194 \\
\hline \multirow{15}{*}{ ДК 445} & \multirow{4}{*}{70} & Контроль (без обр.) & 5,53 & 160,4 & 19,58 & 40,74 & 119,6 & 294 \\
\hline & & Флуоресцин БТ & 6,23 & 180,7 & 17,44 & 41,05 & 139,6 & 340 \\
\hline & & Трихопсин БТ & 6,11 & 177,2 & 17,8 & 41,38 & 135,8 & 328 \\
\hline & & Біоспектр БТ & 5,63 & 163,3 & 19,28 & 41,29 & 122,0 & 295 \\
\hline & \multirow{4}{*}{80} & Контроль (без обр.) & 4,56 & 132,2 & 23,75 & 40,74 & 91,5 & 225 \\
\hline & & Флуоресцин БТ & 5,76 & 167,0 & 22,81 & 41,03 & 126,0 & 307 \\
\hline & & Трихопсин БТ & 6,01 & 174,3 & 18,1 & 41,38 & 132,9 & 321 \\
\hline & & Біоспектр БТ & 6,06 & 175,7 & 17,93 & 41,29 & 134,5 & 326 \\
\hline & \multirow{4}{*}{90} & Контроль (без обр.) & 4,05 & 117,5 & 26,74 & 40,74 & 76,7 & 188 \\
\hline & & Флуоресцин БТ & 4,26 & 123,5 & 25,49 & 41,05 & 82,5 & 201 \\
\hline & & Трихопсин БТ & 4,29 & 124,4 & 25,36 & 41,38 & 83,0 & 201 \\
\hline & & Біоспектр БТ & 4,38 & 127,0 & 24,8 & 41,29 & 85,7 & 208 \\
\hline & & $\mathrm{HIP}_{05}$ для фактора A & 0,21 & & & & & \\
\hline & & HIP $_{05}$ для фрактора B & 0,18 & & & & & \\
\hline & & $\mathrm{HIP}_{05}$ для фрактора C & 0,16 & & & & & \\
\hline
\end{tabular}

препаратами менше впливали на формування площі листкової поверхні, частка їхнього впливу становила відповідно 10,7\% та 27,2\%.

Розрахунки залежності площі листкової поверхні рослин батьківських ліній гібридів кукурудзи показали високий рівень залежності врожайності насіння та площі листкової поверхні. Коефіцієнт кореляції становив 0,556 (рис. 2).

Основним важелем впливу на врожайність насіння були генотипові особливості ліній, група стиглості та біопрепарати. Підвищення густоти рослин мало зворотний вплив на площу листків, що спостерігали в табл. 1, 2.

Проте врожайність, економічні показники вирощування батьківських ліній не були в прямолінійній залежності від густоти рослин. Максимальна врожайність насіння кожної лінії обмежувалася певною щільністю ценозу (табл. 3). Так, скоростигла лінія ДК281 показала максимальну врожайність насіння за густоти рослин 90 тис/га (4,09 т/га). І хоча за такої густоти відзначалося зменшення площі листків рослини порівняно з густотою 70 тис/га, усе ж урожайність насіння підвищувалася зі зменшенням площі листків однієї рослини.
Тому площа листків однієї рослини в межах різної щільності ценозу не може бути показником оптимізації технології вирощування ліній-батьківських компонентів гібридів. Площа листків рослини може бути індикатором дії певного елемента технології (у нашому разі біопрепаратів) за конкретної густоти рослин та конкретної лінії.

Скоростигла лінія ДК281 показала найвищий рівень рентабельності (191\%) та найбільший умовно чистий прибуток (77,9 тис грн/га) за густоти рослин 90 тис/га та обробки препаратом Біоспектр БТ.

Найбільший умовно чистий прибуток та рентабельність у середньоранньої лінії ДК 247 були за густоти рослин 80 тис/га та обробки Біоспектром БТ 98,1 тис грн/га та 241\% відповідно.

Найбільший умовно чистий прибуток та рентабельність у лінії ДК411 були за густоти рослин 80 тис/га та обробки Біоспектром БТ - 91,5 тис грн/га та $224 \%$ відповідно (табл. 4).

Найбільший умовно чистий прибуток та рентабельність у лінії ДК445 (ФАО 430) був за густоти рослин 70 тис/га та обробки Біоспектром БТ - 135,8 тис грн/га та $328 \%$ відповідно. 
Висновки. Біопрепарати Флуоресцин БТ, Трихопсин БТ, Біоспектр БТ на посівах ліній-батьківських компонентів гібридів кукурудзи спричиняють рістрегулюючу дію. Під дією препаратів збільшувалася площа листкової поверхні ліній кукурудзи. Площа листкової поверхні рослин ліній зменшувалася зі збільшенням густоти рослин. На площу листкової поверхні рослин ліній кукурудзи найбільший вплив здійснював генотип батьківської форми, частка його впливу становила $62,1 \%$. Густота рослин та обробіток препаратами менше впливали на формування площі листкової поверхні, частка їхнього впливу становила відповідно $10,7 \%$ та $27,2 \%$.

Площа листкової поверхні рослин батьківських ліній гібридів кукурудзи показала високий рівень залежності врожайності насіння та площі листкової поверхні $(r=0,556)$, що пов'язано з групою стиглості ліній та дією біопрепаратів.

Урожайність, економічні показники вирощування батьківський ліній не були в прямолінійній залежності від густоти рослин. Максимальна врожайність насіння кожної лінії обмежувалася певною щільністю ценозу.

Скоростигла лінія ДК281 (ФАО 190) показала найвищий рівень рентабельності $(191 \%)$ та найбільший умовно чистий прибуток (77,9 тис грн/га) за густоти рослин 90 тис/га та обробки препаратом Біоспектр БТ.

Найбільший умовно чистий прибуток та рентабельність у лінії ДК445 (ФАО 430) був за густоти рослин 70 тис/га та обробки Біоспектром БТ - 135,8 тис грн/га та $328 \%$ відповідно.

Для кожної лінії-батьківського компонента гібриду необхідна індивідуальна технологія вирощування, що передбачає певну густоту рослин та застосування засобів захисту рослин із рістрегулюючою дією.

\section{СПИСОК ВИКОРИСТАНОÏ ЛІТЕРАТУРИ:}

1. Наукове обґрунтування технологій вирощування кукурудзи на зрошуваних землях із урахуванням гідротермічних чинників і змін клімату / Я.М. Гадзало та ін. Зрошуване землеробство. 2020. Вип. 73. С. 21-26. URL: https://doi.org/10.32848/0135-2369.2020.73.13.

2. Assessment of the CROPWAT 8.0 software reliability for evapotranspiration and crop water requirements calculations / R.A. Vozhehova et al. Journal of Water and Land Development. Polish Academy of Sciences (PAN) in Warsaw. 2018. № 39(X-XII). P. 147-152. URL: http://www.degruyter.com/view/j/jwld DOI: 10.2478/ jwld-2018-0070.

3. Черчель В.Ю., Шевченко М.С. Агроресурси і наукове моделювання виробництва 100 мільйонів тонн зерна. Зернові культури. 2020. T. 4. № 1. С. 53-63. URL: https://doi.org/10.31867/2523-4544/0106.

4. Кирпа М.Я. Методологія визначення якості насіння зернових культур. Бюлетень Інституту сільськогосподарської степової зони НААН. 2016. № 10. C. $20-25$.

5. Кирпа М.Я., Ковальов Д.В. Особливості проростання насіння гібридів кукурудзи залежно від його крупності. Зернові культури. 2020. Т. 4. № 1. С. 46-52. URL: https://doi.org/10.31867/2523-4544/0105.

6. Крутякова В.І. Біометод - основа сталого розвитку вітчизняного землеробства. Вісник аграрної науки. 2020. № 10. C. 5-14. DOI: https://doi.org/10.31073/ agrovisnyk202009-01.
7. Мікробні препарати в сучасних аграрних технологіях / В.В. Волкогон та ін. Київ : НААН. 248 с.

8. Крутякова В.І., Таргоня В.С. Багаторівнева система сертифікації органічних виробництв сільськогосподарської продукції. Біологічний метод захисту рослин: досягнення і перспективи. Інформаційний бюлетень Східно-палеарктичної регіональної секції Міжнародної організації з біологічної боротьби зі шкідливими організмами. 2018. № 53. С. 185-191.

9. From the Lab to the Farm: An Industrial Perspective of Plant Beneficial Microorganisms / J.J. Parnell et al. Front Plant Sci. 2016. V. 7. P. 1110. DOI: 10.3389/ fpls.2016.01110.

10. Biological control using invertebrates and microorganisms: plenty of new / J.C. Van Lenteren et al. BioControl. 2018. V. 63. P. 39-59. DOI: 10.1007/ s10526-017-9801-4.

11. Marchenko T.Yu. Innovative elements of cultivation technology of corn hybrids of different FAO groups in the conditions of irrigation. Natural sciences and modern technological solutions: knowledge integration in the $X X I$ century : collective monograph. Lviv-Torun : Liha-Pres, 2019. P. 137-153. URL: https://doi.org/10.36059/978-966-397-154-4/135-152.

12. Бєлов Я.В. Напрями оптимізації технологій вирощування насіння кукурудзи за умов змін клімату. Вісник аграрної науки Причорномор'я. 2018. № 4. С. 74-81. DOl.org: 10.31521/2313-092X/2018-4(100)-11.

13. Вожегова Р.А., Хоменко Т.М. Особливості формування фотосинтетичного потенціалу і врожайності насіння батьківських компонентів кукурудзи в умовах зрошення та застосування стимулятора росту. Plant Varieties Studying and protection. 2020. T. 16. № 2. C. 191-198. URL: http://doi.org/ 10.21498/2518-1017.16.2.2020.209239.

14. Вожегова Р.А., Лавриненко Ю.О., Марченко Т.Ю. Продуктивність ліній - батьківських компонентів гібридів кукурудзи залежно від способів поливу та густоти рослин у Південному Степу. Вісник аграрної науки. Генетика, селекція, біотехнологія. 2020. № 2(803). C. 58-63. URL: https://doi.org/10.31073/ agrovisnyk202002-11S.

15. Черчель В.Ю., Марочко В.А., Таганцова М.М. Обґрунтування індексу співвідношення висоти прикріплення верхнього качана до висоти рослини гібридів кукурудзи (Zea mays L.). Plant Varieties Studying and Protection. 2014. № 2(23). C. 37-39. URL: https://doi.org/10.21498/2518-1017.2(23).2014.56127.

16. Рекомендації Інженерно-технологічного інституту «Біотехніка» НАAН (м. Одеса). URL: https:// biotekhnika.od.ua/uk (дата звернення: 12.03.2019).

17. Методика польових і лабораторних досліджень на зрошуваних землях / Р.А. Вожегова та ін. Херсон : Грінь Д.С., 2014. 286 с.

18. Продуктивність та стійкість до уражень біотичними чинниками ліній-батьківських компонентів гібридів кукурудзи за використання біопрепаратів в умовах зрошення / Т.Ю. Марченко та ін. Селекція $і$ насінництво. 2020. № 118. C.130-139. URL: https:// doi.org/10.30835/2413-7510.2020.222395.

\section{REFERENCES:}

1. Gadzalo, Y.M., Vozhegova, R.A., Kokovikhin, S.V., Bilyaeva, I.M., \& Drobitko, A.V. (2020). Naukove 
obgruntuvannya tekhnolohiy vyroshchuvannya kukurudzy na zroshuvanykh zemlyakh iz urakhuvannyam hidrotermichnykh chynnykiv i zmin klimatu. [Scientific substantiation of technologies of corn cultivation on irrigated lands taking into account hydrothermal factors and climate change]. Zroshuvane zemlerobstvo. Zbirnyk naukovykh prats - Irrigated agriculture. Collection of scientific works. 73. 21-26. https://doi.org/10.32848/0135-2369.2020.73.13 [in Ukrainian].

2. Vozhehova, R.A., Kokovikhin, S.V., Lykhovyd, P.V., Biliaeva, I.M., Drobitko, A.V., \& Nesterchuk, V.V. (2018). Assessment of the CROPWAT 8.0 software reliability for evapotranspiration and crop water requirements calculations. Journal of Water and Land Development. Polish Academy of Sciences (PAN) in Warsaw. 39 (X-XII). 147-152. http://www.degruyter.com/view/j/ jwld DOI: 10.2478/jwld-2018-0070 [in English].

3. Cherchel, V.Yu., \& Shevchenko, M.S. (2020). Ahroresursy i naukove modelyuvannya vyrobnytstva 100 milyoniv tonn zerna. [Agricultural resources and scientific modeling of production of 100 million tons of grain]. Zernovi kultury - Grain crops. 4(1). 53-63. https://doi.org/10.31867/2523-4544/0106 [in Ukrainian].

4. Kyrpa, M. Ya. (2016). Metodolohiya vyznachennya yakosti nasinnya zernovykh kultur [Methodology for determining the quality of seeds of cereals]. Byul. In-tu s.-h. hosp. stepovoyi zony NAAN - Bulletin of Institutes grain crops of. steppe zone of NAAS. Dnepropetrovsk. 10. 20-25 [in Ukrainian].

5. Kyrpa, M. Ya., \& Kovalev, D.V. (2020). Osoblyvosti prorostannya nasinnya hibrydiv kukurudzy zalezhno vid yoho krupnosti. [Features of germination of seeds of hybrids of corn depending on its size]. Zernovi kultury - Grain crops. 4(1). 46-52. https://doi. org/10.31867/2523-4544/0105 [in Ukrainian].

6. Krutyakova, V.I. (2020). Biometod - osnova staloho rozvytku vitchyznyanoho zemlerobstva. [Biomethod - the basis of sustainable development of domestic agriculture]. Visnyk ahrarnoyi nauky Bulletin of Agricultural Science. 10. 5-14. DOI: https:// doi.org/10.31073/agrovisnyk202009-01 [in Ukrainian]

7. Volkogon, V.V., Zarishnyak, A.S., \& Pilipenko, L.A (2018). Mikrobni preparaty $v$ suchasnykh ahrarnykh tekhnolohiyakh. [Microbial preparations in modern agricultural technologies]. Kyiv: NAAS. 248. [in Ukrainian]

8. Krutyakova, V.I., \& Targonya, V.S. (2018). Bahatorivneva systema sertyfikatsiyi orhanichnykh vyrobnytstv silskohospodarskoyi produktsiyi [Multilevel system of certification of organic agricultural production]. Biolohichnyy metod zakhystu roslyn: dosyahnennya i perspektyvy. Informatsiynyy byuleten' Skhidnopalearktychnoyi rehionalnoyi sektsiyi Mizhnarodnoyi orhanizatsiyi z biolohichnoyi borot'by zi shkidlyvymy orhanizmamy - Biological method of plant protection: achievements and prospects. Newsletter of the East Palearctic Regional Section of the International Organization for Biological Pest Control. 53. 185-181. [in Ukrainian].

9. Parnell, J.J., Berka, R., \& Young, H.A. (2016). From the Lab to the Farm: An Industrial Perspective of Plant Beneficial Microorganisms. Front Plant Sci. 7. 1110. DOI: 10.3389/fpls.2016.01110 [in English]
10. Van Lenteren, J.C., Bolckmans, K., \& Köh, J. (2018). Biological control using invertebrates and microorganisms: plenty of new. BioControl. 63. 39-59. DOI: 10.1007/s10526-017-9801-4 [in English]

11. Marchenko T. Yu. (2019). Innovative elements of cultivation technology of corn hybrids of different FAO groups in the conditions of irrigation. Natural sciences and modern technological solutions: knowledge integration in the XXI century: collective monograph Lviv-Torun: Liha-Pres, 137-153. DOI: https://doi.org/ 10.36059/978-966-397-154-4/135-152 [in English].

12. Belov, Ya.V. (2018). Napryamy optymizatsiyi tekhnolohiy vyroshchuvannya nasinnya kukurudzy za umov zmin klimatu. [Directions for optimizing technologies for growing corn seeds under climate change]. Visnyk ahrarnoyi nauky Prychornomor'ya - Bulletin of Agrarian Science of the Black Sea Coast. 4. 74-81. doi.org:10.31521/2313-092X/4(100)11 [in Ukrainian].

13. Vozhegova, R.A., \& Khomenko, T.M. (2020). Features of formation of photosynthetic potential and seed yield of parent components of corn in the conditions of irrigation and application of growth stimulator. Plant Varieties Studying and protection. 16(2). 191-198. DOI: http://doi.org/10.21498/2518-1017.16.2.2020.209239 [in English].

14. Vozhegova, R.A., Lavrynenko, Y.O., \& Marchenko, T.Yu. (2020). Produktyvnist liniy - batkivskykh komponentiv hibrydiv kukurudzy zalezhno vid sposobiv polyvu ta hustoty roslyn u Pivdennomu Stepu [Productivity of lines - parent components of maize hybrids depending on watering methods and plant density in the Southern Steppe]. Visnyk ahrarnoyi nauky - Bulletin of Agricultural Science. Genetics, selection, biotechnology. 2(803). 58-63. https://doi.org/10.31073/agrovisnyk202002-11S [in Ukrainian].

15. Cherchel, V.Yu., Marochko, V.A., \& Tagantsova, M.M. (2014). Obhruntuvannya indeksu spivvidnoshennya vysoty prykriplennya verkhn'oho kachana do vysoty roslyny hibrydiv kukurudzy (Zea mays L.). [Substantiation of the index of the ratio of the height of attachment of the upper cob to the height of the plant hybrids of corn (Zea mays L.)]. Plant Varieties Studying and Protection. 2(23). 37-39. DOI: https:// doi.org/10.21498/2518-1017.2(23).2014.56127 [in Ukrainian].

16. Rekomendatsiyi Inzhenerno-tekhnolohichnohoinstytutu "Biotekhnika" NAAN (m.Odesa) [Recommendations of the Engineering and Technological Institute "Biotechnology" NAAS (Odessa)]. https://biotekhnika. od.ua/uk (accessed March 12, 2019)

17. Vozhehova, R.A., \& Malyarchuk, M.P. (2014). Metodyka polovykh i laboratornykh doslidzhen na zroshuvanykh zemlyakh. [Methods of field and laboratory research on irrigated lands]. Kherson: Grin DS. 286 p.

18. Marchenko, T.Yu., Lavrinenko, Y.O., Kirpa, M.Ya., \& Stasiv, O.F. (2020). Produktyvnist ta stiykist do urazhen biotychnymychynnykamyliniy-bat'kivskykhkomponentiv hibrydiv kukurudzy za vykorystannya biopreparativ $v$ umovakh zroshennya. [Productivity and resistance to damage by biotic factors of parental components of maize hybrids with the use of biological products under irrigation]. Selektsiya i nasinnytstvo - Breeding and seed production. 118. 130-139. DOI: https:// doi.org/10.30835/2413-7510.2020.222395. 
Марченко Т.Ю., Лавриненко Ю.О., Кирпа М.Я., Стасів О.Ф. Ефективність застосування біопрепаратів під час вирощування ліній-батьківських компонентів гібридів кукурудзи за різної густоти рослин в умовах краплинного зрошення

Мета. Удосконалення технології вирощування ліній-батьківських компонентів інноваційних гібридів кукурудзи на зрошуваних землях шляхом визначення впливу нових біопрепаратів за різної густоти рослин на врожайність насіння та економічну ефективність за умов зрошення в Південному Степу; встановлення впливу різних умов проморожування на якість насіння гібридів кукурудзи залежно від їх збиральної вологості і способів сушіння. Методи. Польові - з обліку врожайності, лабораторні - 3 визначення показників якості насіння; біометричні - з визначення особливостей росту і розвитку рослин батьківських ліній гібридів кукурудзи; статистичні - 3 установлення достовірності отриманих результатів. Результати. Встановлено, що найбільший вплив площу листків рослин ліній кукурудзи мала батьківська форма, частка її впливу становила $62,1 \%$. Густота рослин та обробіток препаратами менше впливали на формування площі листкової поверхні, частка їхнього впливу становила відповідно $10,7 \%$ та $27,2 \%$. За обробітку препаратом Флуоресцин БТ усі лінії-батьківські компоненти гібридів кукурудзи мали найвищі показники площі листкової поверхні рослин. У наступні фази розвитку рослин культури відбувалося незначне зменшення даного показника, тому площа листків однієї рослини в межах різної щільності ценозу не може бути показником оптимізації технології вирощування ліній-батьківських компонентів гібридів. Площа листків рослини може бути індикатором дії певного елемента технології (в нашому разі біопрепаратів) за конкретної густоти рослин та конкретної лінії. Площа листкової поверхні рослин - батьківських ліній гібридів кукурудзи показала високий рівень залежності врожайності насіння та площі листкової поверхні. Коефіцієнт кореляції становив 0,556. Скоростигла лінія ДК281 показала найвищий рівень рентабельності (191\%) та найбільший умовно чистий прибуток $(77,9$ тис грн/га) за густоти рослин 90 тис/ га та обробки препаратом Біоспектр БТ. Найбільший умовно чистий прибуток та рентабельність у середньоранньої лінії ДК 247 були за густоти рослин 80 тис/га та обробки Біоспектром БТ - 98,1 тис грн/га та 241\% відповідно. Найбільший умовно чистий прибуток та рентабельність у лінії ДК 411 були за густоти рослин 80 тис/га та обробки Біоспектром БТ - 91,5 тис грн/га та $224 \%$ відповідно. Найбільший умовно чистий прибуток та рентабельність у лінії ДК 445 (ФАО 430) був за густоти рослин 70 тис/га та обробки Біоспектром БТ - 135,8 тис грн/га та $328 \%$ відповідно. Висновки. Біопрепарати Флуоресцин БТ, Трихопсин БТ, Біоспектр БТ на посівах ліній-батьківських компонентах гібридів кукурудзи спричиняють рістрегулюючу дію. Під дією препаратів збільшувалася площа листкової поверхні ліній кукурудзи. Площа листкової поверхні рослин ліній зменшувалася зі збільшенням густоти рослин. Для кожної лінії-батьківського компонента гібриду необхідна індивідуальна технологія вирощування, що передбачає певну густоту рослин та застосування засобів захисту рослин із рістрегулюючою дією.

Ключові слова: кукурудза, лінії, батьківські компоненти, урожайність, насіння, біопрепарати.
Marchenko T.Yu., Lavrynenko Yu.O., Kyrpa M.Ya., Stasiv O.F. The effectiveness of biological products in the cultivation of parental components of maize hybrids at different plant densities under drip irrigation

Purpose. Improving the technology of growing parental lines of innovative maize hybrids on irrigated lands by determining the impact of new biological products at different plant densities on seed yield and economic efficiency under irrigation in the Southern Steppe. Establishing the influence of different freezing conditions on the seed quality of maize hybrids depending on their harvesting moisture and drying methods. Methods. Field on the account of productivity, laboratory on definition of indicators of quality of seeds; biometric to determine the peculiarities of growth and development of plants of the parental lines of maize hybrids; statistical to establish the reliability of the results. Results. It was found that the greatest influence on the leaf area of corn line plants had the parental form, the share of its influence was $(62.1 \%)$. Plant density and drug treatment had less effect on the formation of leaf surface area, the share of their impact was 10.7 and $27.2 \%$, respectively. When treated with Fluorescein BT, all parent lines of maize hybrids had the highest leaf surface area of plants. In the following phases of development of plants of culture there was a slight decrease in this indicator. Therefore, the area of leaves of one plant within different densities of the coenosis can not be an indicator of optimization of technology for growing lines-parent components of hybrids. The area of plant leaves can be an indicator of the action of a certain element of technology (in our case, biological products) at a specific plant density and a specific line. The leaf surface area of plants of the parental lines of maize hybrids showed a high level of dependence of seed yield and leaf surface area. The correlation coefficient was 0.556 . The early-maturing line DK281 showed the highest level of profitability (191\%) and the highest conditionally net profit (77.9 thousand $\mathrm{UAH} / \mathrm{ha}$ ) for plant densities of 90 thousand/ha and treatment with Biospectrum BT. The largest conditionally net profit and profitability in the middleearly line DK247 were for plant densities of 80 thousand/ ha and processing Biospectrum BT - 98.1 thousand UA/ ha and $241 \%$, respectively. The largest conditionally net profit and profitability in the line of DC 411 were for plant densities of 80 thousand/ha and processing Biospectrum BT - 91.5 thousand $\mathrm{UAH} / \mathrm{ha}$ and $224 \%$, respectively. The largest conditionally net profit and profitability in the line DK 445 (FAO 430) was at a plant density of 70 thousand / ha and processing Biospectrum BT - 135.8 thousand UAH/ ha and $328 \%$, respectively. Conclusions. Biopreparations Fluorescein BT, Trichopsin BT, Biospectrum BT on crops of parental components of maize hybrids cause growth regulatory action. Under the action of drugs, the leaf surface area of corn lines increased. The leaf area of plant lines decreased with increasing plant density. For each line-parent component of the hybrid requires individual cultivation technology, which provides a certain density of plants and the use of plant protection products with growth-regulating action.

Key words: corn, lines, parental components, yield, seeds, biological products. 